Research Report 1694

\title{
A Strategy for Efficient Device-Based Tank Gunnery Training in the Army National Guard
}

\author{
Joseph D. Hagman \\ U.S. Army Research Institute \\ John E. Morrison \\ Institute for Defense Analyses
}
Reserve Component Research Unit
Ruth H. Phelps, Chief

U.S. Army Research Institute for the Behavioral and Social Sciences 5001 Eisenhower Avenue, Alexandria, Virginia 22333-5600

Office, Deputy Chief of Staff for Personnel

Department of the Army

$$
\text { June } 1996
$$

